\title{
STEPPING AWAY FROM THE STATE
}

\section{Kenneth Keith ${ }^{*}$}

\begin{abstract}
Judge Kenneth Keith delivered the Keynote Address of the Third Annual CJICL Conference on Saturday 10 May 2014 at the Divinity School of St John's College in the University of Cambridge. He spoke to the Conference theme of 'Stepping Away from the State', and detailed the various institutions that may exist outside of the state but nevertheless prove capable of producing rules that provide structure to human interaction and which may furthermore contribute to the wider development of public international law.
\end{abstract}

The difficulty lies, not in the new ideas, but in escaping from the old ones, which ramify, for those of us brought up as most of us have been, into every corner of our minds. ${ }^{1}$

\section{1 'Escaping from old ideas...'}

My task is to question the state-centric view of the law that so many lawyers, national, comparative or international, have. So, international law is very often defined in the first words of books on the subject as law operating between states and made by them. Descriptions of national legal systems generally have state institutions-legislatures, courts and executives-at their centre. Think of the lists of references found at the outset of many law books-constitutions, statutes, subordinate legislative instruments, treaties and cases-sometimes only the last which highlights the all too frequent court-centred perspective of the writer.

What I suggest we do is to think in a different way about the systems, the institutions, the rules and the practices we are all familiar with, looking away from, or even ignoring, the State. Think about the various institutions and groups we all belong to-families, schools and universities, religious bodies, sports and other clubs and no doubt many others, especially in this electronic age, and their rules, practices, processes and institutions. There is a danger of our getting

\footnotetext{
Judge, International Court of Justice. My thanks to Amelia Keene for her comments on this lecture.

1 J M Keynes, General Theory of Employment, Interest and Money (1935) preface.
} 
trapped in familiar narrow patterns if we use ideas or terms like 'the state' or its close relatives 'sovereign' or 'sovereignty' without challenging them from time to time. You might like to consider a lecture given about 10 years ago in this university in honour of a great law professor and Vice-Chancellor under the title 'Sovereignty at the Beginning of the 21st Century: Fundamental or Outmoded?', and an excellent essay by the holder of the Whewell Chair in Public International Law, 'Sovereignty as a Legal Value.' ${ }^{3}$ The former quotes this wise caution from 180 years ago stated by the great American judge and scholar, Joseph Story: "the term "sovereign" or "sovereignty" is used in different senses which often leads to a confusion of ideas, and sometimes to very mischievous and unfounded conclusions.' ${ }^{4}$

To be a little concrete, I begin with the place we are, in a divinity school, in a university, with a rugby ground not far away. Organised religions and universities, their systems, institutions, rules and practices, go back to times long before the establishment of the modern state, with its systems. They did not 'step away' from the state-they preceded it. The same cannot be said of rugby, but as with religion and universities, the state did not establish its systems, institutions, rules and practices. Rather, representatives of individual clubs playing various forms of 'football' came together in London restaurants or public houses to write the rules and create the unions and associations. ${ }^{5}$ The state, through its agencies and laws, generally has a limited role, if any, in respect of their laws, institutions and operations. That is too absolute a statement and I will qualify it in the course of this paper. Let me first mention two recent books which I have found stimulating in thinking about this paper. Each has the value, as I see it, of being written by a philosopher, in the one case, and by a sociologist, in the other-and not by lawyers. Looking back over my reading, listening and thinking over many years since I first studied law, I would urge you to read, listen and think well beyond the law.

The first of two books is by John Searle, a professor of mind and language at University of California, Berkeley. It is called Making the Social World: The

${ }^{2}$ KJ Keith, 'Sovereignty at the beginning of the 21st Century: Fundamental or outmoded?' (2004) 63 CLJ 581.

3 J Crawford, 'Sovereignty as a Legal Value', in J Crawford \& M Koskenniemi (eds) The Cambridge Companion to International Law (2013) 117.

${ }^{4}$ Joseph Story, Commentaries on the Constitution of the United States, vol 1(1833) book 2, para 207.

5 See e.g. Melvyn Bragg, 'The Book of Rules of Association Football (1863)', in Melvyn Bragg, Twelve Books that Changed the World (2006). For a fascinating bottom up account of the formulation of the 'rules of the game', in this particular case the rules of marbles, see Jean Piaget, The Moral Judgment of the Child (1932, tr 1962). 
Structure of Human Civilisation, and in it he develops a three part thesis:

1. all human institutional reality is created by a single logico-linguistic operation;

2. this operation he calls a 'Status Function Declaration'; and

3. this operation is not restricted in subject matter. ${ }^{6}$

Think of the ways in which the institutions you know are created and operated. Does this thesis work? Does it help explain those institutions and those I discuss?

You may find more interesting and richer in historical reference and reasoning Richard Sennett's Together: The Rituals, Pleasures and Politics of Cooperation, one of three books (one still to come) he is writing about the skills people need to sustain everyday life. ${ }^{7}$ He begins with the 'Cooperative Frame of Mind' (instancing musical rehearsals and the use of the subjunctive). Next he considers 'Cooperation Shaped', ending with Hans Holbein the Younger's The Ambassadors (1533). That painting, he says, marks (1) the Reformation, with an open printed hymnal in the native language, (2) changes in the organisation of workshops, with precision instruments for navigation on show, (3) a death's head, visible only when the painting is viewed from the side, a symbol of the vanity of human wishes and (4) the two young men, not ambassadors in the strict sense but envoys sent to London by Catholic France to deal with the turmoil caused by Henry VIII's marital troubles. We would now say they were on a special mission. Sennett's third part is about 'Cooperation Weakened' dealing with matters which are increasingly in public debate-growing inequality, embittered social relations at work and the uncooperative self, arising from withdrawal. ${ }^{8}$ The book ends, subject to a Coda, with an upbeat part headed 'Cooperation Strengthened', discussing the workshop (making and repairing), every day diplomacy (with valuable comments on indirection and silence, as well as on active participation) and the community in which commitment is practiced. The Coda is about Montaigne's cat: When I am playing with my cat, how do I know she is not playing with me? For Sennett, Montaigneborn in the year The Ambassadors was painted-was asking what passes in the

\footnotetext{
${ }^{6}$ John Searle, Making the Social World: the Structure of Human Civilisation (2009) 201.

7 Throughout this part, see generally Richard Sennett, Together: The Rituals, Pleasures and Politics of Cooperation (2012).

${ }^{8}$ See e.g. Ferdinand Mount, The New Few: or a Very British Oligarchy (2012) and Thomas Piketty, Capital in the Twenty-First Century (2014) and the controversy it has caused.
} 
minds of those with whom we cooperate? Montaigne, he says, was concerned with aspects of practicing cooperation: dialogic (not dialectic) practices which are skilled, informal and empathic.

I have engaged in this summary of an excellent book to emphasise the centrality of cooperation in human existence, a centrality deeply embedded in much law, particularly international law. It also helps lead into the areas of law and practice which I will consider. But before I enter into those areas, one general comment on cooperation in international law and one further reference to another outstanding scholar, this time a lawyer.

The general comment relates to the development of international law over the course of the last two centuries. The law of relations between States in a narrow sense, the law of coexistence, has been increasingly supplemented by a law of cooperation, for instance in the 19th century in the treaties setting up the commissions and rules to regulate major European rivers and the institutions regulating the post and telegraph, and, more generally, in the Charter of the United Nations (Article 1(3) and Chapter IX) and in the 1970 Declaration on Principles of International Law concerning Friendly Relations and Cooperation among States in accordance with the Charter of the United Nations and in the duty of cooperation spelled out there-the title to which is too often wrongly abridged, by me among others. ${ }^{9}$ Fifty years ago Wolfgang Friedmann had recorded and assessed these major changes in his outstanding Changing Structure of International Law. ${ }^{10}$

I have one last reference before I consider a range of institutions and systems set up in large part, or even in full, away from the state. It is to another great legal scholar of the mid 20th century, Lon L Fuller. In his 1969 paper, 'Two Principles of Human Association,'11 he begins with himself and four of his fifth grade classmates who used to gather at lunchtime in the corner of the playground to discuss Idylls of the King and Treasure Island and to engage in a game of literary one-upmanship. Wilber, a somewhat unprepossessing classmate, hovered about and reluctantly they let him join. They soon realised they had made a bad mistake. They decided they had to expel him. How should they communicate their decision? This had to be accomplished in a manner befitting the literary dedication of their society-by giving him a Black Spot, a negative judgment as in Treasure Island. ${ }^{12}$

\footnotetext{
${ }^{9}$ GA Res 2625 (XXV) (24 October 1970).

${ }^{10}$ Wolfgang Friedmann, Changing Structure of International Law (1964).

${ }^{11}$ Republished in Kenneth I Winston (ed), The Principles of Social Order: Selected Essays of Lon L Fuller (revised edn, 2001) 101.

${ }^{12}$ Robert Louis Stevenson, Treasure Island (1883) ch 3.
} 
Wilber could not fail to understand what they meant. They drew straws to select the messenger. Fuller has written very interestingly about the use of lot, along with other means, in resolving issues. ${ }^{13}$ Wilber did not understand the message and broke into tears. Years later, Fuller was sharply reminded of the Petition of Wilber $v$ The Young Literary Snobs when he became aware of the decision of a New York Appellate Court upholding the summary dismissal by Syracuse University of Susan Anthony at the beginning of her fourth year in home economics. ${ }^{14}$ The only justification given by the University was that she was 'not a typical Syracuse girl'. Fuller thought that the failure of the University to specify grounds and to give Miss Anthony a hearing was outrageous. But then he wondered whether a formal hearing devoted to the issue: is she or is she not 'the type' would call to mind the horrors of Kafka's The Trial ${ }^{15}$ and the caricature of the judicial office presented by the Red Queen when she sat in judgment of Alice. ${ }^{16}$

Fuller then goes on to discuss, by contrast to the principle of associations formed by 'shared commitment', 'the legal principle'-that is the situation with which, as lawyers, we are more familiar. The association is held together and enabled to function by formal rules of duty and entitlement. Very often of course the two will go together. A formal relationship-a marriage, a law firm partnership, a coalition government, a church, an alliance between states for instance-may well come apart if the shared commitment fails and creeping or galloping legalism prevails. Recall Alexander Pope's lines: 'For forms of Government, let fools contest / Whate'er is best administer'd is best.' ${ }^{17}$

Against that broad background, I now consider a wide range of bodies, groups, systems which, in some degree or other, are or wish to be outside the state and its legal system and the international legal system. As I run through them I will raise questions about the extent to which those bodies are or should be outside the law. Later, I discuss other bodies, separate from the state, which do

\footnotetext{
${ }^{13}$ Winston (ed), above $\mathrm{n} 11,41,189-90,218$. One nice coincidence is that lot was used in a case in the International Court between Malaysia and Singapore to determine which pleaded first in a dispute about sovereignty over a small island and certain maritime features; the light on the top of the lighthouse erected on the island was made by another member of the Stevenson family who were major lighthouse builders: Sovereignty over Pedra Branca/Pulau Batu Puteh, Middle Rocks and South Ledge (Malaysia/Singapore), ICJ Reports 2008 p 12, 20.

${ }^{14}$ Anthony v Syracuse University, 223 NY Supp 796 (1927); 224 App Div 487 (1928).

${ }^{15}$ Franz Kafka, The Trial (1925).

${ }^{16}$ Lewis Carroll, Alice's Adventures in Wonderland (1865) chs 11 \& 12.

${ }^{17}$ Alexander Pope, Essay on Man (1732-1733) epistle iii, line 303. Fuller quotes this remark of a well-known theologian: 'when the spirit of God has burnt itself out, or lost its vigor, Canon Law proliferates': above $\mathrm{n} 11,94$.
} 
engage with the state and its legal system or with the international legal system. That may indeed be their purpose, or, if not, the effect of their activities. In the final part of the paper I examine two cases of an international character in which the courts drew on a wide range of sources.

\section{Bodies away from the state and wishing to remain so}

I consider an array of such bodies, beginning with my earlier reference to organised religion, universities and sport. National litigation and legislation and international law are now to be seen in all three areas, in the third increasingly so, as more and more sport becomes professional and international big businesses, and fraud and cheating raise their ugly heads. But matters of religious belief, academic scholarship and 'the rules of the game' remain in large measure unregulated by public law-although with challenges increasingly being presented on the basis of universal human rights. Those matters remain essentially with those with the shared commitment.

Second, are bodies operating internationally in broadly commercial areas. Major corporates may provide in their contracts for private arbitration and aim to exclude national courts insofar as they can. ${ }^{18}$ A notable English commercial lawyer of the 1920s, Lord Justice Scrutton, declared of such clauses that there must be no Alsatia in England where the King's writ does not run. ${ }^{19}$ 'Alsatia' is used by the judge as a reference to an area of London which in the $17^{\text {th }}$ century was a refuge for many criminals and where the execution of a warrant was attended with great danger. Over the years in different countries, different professional, legislative and judicial views have been adopted about the balance between the autonomy of the parties and the requirements of the legal system in which issues about the arbitral process and the award may arise by way of enforcement or

${ }_{18}$ For a recent account see 'Exorbitant Privilege' (The Economist, 10 May 2014).

${ }^{19}$ Czarnikow v Roth, Schmidt $\mathcal{E}$ Co [1922] 2 KB 478, 488 (CA). As recently as 2007 another notable member of the Court of Appeal of England and Wales made a different use of the reference when he declared that 'in setting up the Serious Organised Crime Agency the State has set out to create an Alsatia, a region of executive action free of judicial oversight': UMBS v SOCA [2007] EWCA Civ 406, para 58. Christiania in Copenhagen provides a very different further example of a self-proclaimed autonomous community. It was set up in a few streets 40 years ago inside an old Danish military base. A modern day Alsatia, perhaps? See Tom Freston, 'You Are Now Leaving the European Union' (Vanity Fair, 12 September 2013). But what about garbage collection, water supply, heath care, pensions and rates-not to mention criminal law enforcement? 
annulment. ${ }^{20}$ One notable instance of an international business running its own legal system of self-regulation is provided by the world diamond industry. ${ }^{21}$ The author of a valuable study of that industry begins with this description:

The diamond industry has systematically rejected state-created law. In its place, the sophisticated traders who dominate the industry have developed an elaborate, internal set of rules, complete with distinctive institutions and sanctions, to handle disputes among industry members. ${ }^{22}$

She ends with this passage which may be related back to Lon Fuller's principle of shared commitment:

In the diamond industry, 'trust' and 'reputation' have an actual market value. As an elderly Israeli diamond dealer explained [...] 'when I first entered the business, the conception was that truth and trust were simply the way to do business, and nobody decent would consider doing it differently. Although many transactions are still consummated on the basis of truth and truthfulness, this is done because these qualities are viewed as good for business, a way to make a profit. $^{, 23}$

Another example under this broad heading consists of the international ratings agencies, such as Standard and Poor's, Moody's and IHS. ${ }^{24}$ They in fact exercise huge power-as smaller national credit rating agencies also do in their areas-over national economies, particularly over their ability to borrow. There are occasional, it seems very occasional, law suits brought against them for negligence and for anti-competitive behaviour. But they do appear to operate in significant part beyond the law.

My final instance of bodies that operate outside the state are the Mafia in its various forms $\mathrm{s}^{25}$-organisations created for profit, bound by an oath of

\footnotetext{
${ }^{20}$ See e.g. New Zealand Law Commission Report No 20: Arbitration (1991).

${ }^{21}$ See e.g. Lisa Bernstein, 'Opting out of the Legal System: Extra Legal Contractual Relations in the Diamond Industry' (1992) 21 JLS 115.

${ }^{22}$ Ibid, 115.

${ }^{23}$ Ibid, 157 (emphasis original).

${ }^{24}$ See e.g. Benedict Kingsbury, Governance by Indicators (2012).

${ }^{25}$ See e.g. Misha Glenny, McMafia: Crime without Frontiers (2008).
} 
silence-omerta-and more broadly transnational organised crime. ${ }^{26}$ They are of course set up to operate outside and in breach of the relevant law but with their own systems nonetheless. This instance highlights the need for strong national law enforcement, increasingly backed by treaties and related arrangements. Those treaties can be traced back to the $19^{\text {th }}$ century slavery treaties with many more being adopted in the last century, notably the UN Convention against Transnational Organised Crime and the UN Convention against Corruption. ${ }^{27}$ Among the many related arrangements are those administered by the Financial Action Task Force established by the G7 in 1989 'to set standards and promote effective implementation of legal, regulatory and operational measures for combatting money laundering, terrorist financing and other related threats to the integrity of the international financial system. ${ }^{28}$

\section{Bodies away from the state or the international legal system and contributing to the law or its operation}

This grouping of bodies which are to a greater or lesser degree independent of states but which may contribute to the making of the law or to its practical content, at national, regional and international levels, has very many members. I am very selective. Three subgroups can be identified: first, those groups that are set up to develop or codify law or to assist with the process; second, those that establish terms of trade for ease of usage; and third, the practices and standards developed by occupational groups.

The first is exemplified by bodies such as the International Law Commission and national law (reform) commissions, on the one side, and the Institut de Droit international and the American Law Institute, on the other, the former pair being established by states, but with a certain independence, and the latter by private initiative and with full independence. Each of these bodies has a general mandate over the whole of international law or national law as the case may be. Others will

\footnotetext{
${ }^{26}$ See e.g. Moises Naim, Illicit: How Smugglers, Traffickers and Copycats are Hijacking the Global Economy (2006).

${ }^{27}$ UN Convention against Transnational Organised Crime, 15 November 2000, 2225 UNTS 209; UN Convention against Corruption, 31 October 2003, 2349 UNTS 41. For an earlier still valuable account see R S Clark, 'Offences of International Concern: Multilateral State Treaty Practice in the Forty Years since Nüremberg' (1988) 57 Nordic JIL 49.

${ }^{28}$ See <http://www.fatf-gafi.org/pages/aboutus/> [accessed 7 November 2014].
} 
have a particular focus, such as the International Committee of the Red Cross which had its beginnings 150 years ago and has large responsibilities in respect of the preparation of the drafts of Geneva Conventions for the protection of the victims of armed conflict and their implementation. Another is the Comité Maritime International, an international NGO founded in 1897 and made up of national NGOs, with the purpose of contributing in all appropriate ways to the unification of maritime law in all its aspects. Its work has provided the basis for several major maritime treaties, work which in recent years has been handled through the Legal Committee of the International Maritime Organisation. More recent instances are NGOs concerned with human rights (although antislavery bodies can be traced back to the $18^{\text {th }}$ century), environmental matters and international criminal law. ${ }^{29}$

Those bodies illustrate, in their establishment and their operation, choices to be made. So far as their establishment is concerned, the founders of the Institut de Droit international took the view that the codification and development of international law was too important to be left to governments, it was to be an exclusively learned society, without any official nature, and with the purpose of promoting international law. In the 1920s, by contrast, the Member States of the League of Nations decided that they should undertake the task of codification, work that was however preceded by a report of a Committee of Experts-an effort which essentially failed. ${ }^{30}$ In 1947 the General Assembly took a middle course when it set up the International Law Commission consisting of individuals who are to be persons of recognised competence in international law. They sit in their individual capacities and not as government representatives. It follows that they cannot be replaced by alternates. They are however elected by states on the nomination of states; further, the proposal that the nomination and election of the Commission's members be modelled on that for the ICJ was rejected on the basis that the Court was a special case and the work of codification had been entrusted to the General Assembly by Article 13 of the Charter. ${ }^{31}$

By contrast, other bodies established by the General Assembly to address matters of the codification and progressive development of international law consist of Member States but with a recommendation to them that they appoint persons of appropriate calibre and qualifications. ${ }^{32}$

\footnotetext{
${ }^{29}$ See e.g. Alan Boyle \& Christine Chinkin, The Making of International Law (2007) 77-97.

${ }^{30}$ Report of the International Law Commission on the work of its $64^{\text {th }}$ session, UN Doc A/67/10 (3 August 2012) 3-4.

${ }^{31}$ Ibid, 10.

${ }^{32}$ See e.g. GA Res 1966 (XVIII) (16 December 1963) para 2 (regarding the Special Committee on
} 
A second matter of choice relates to the form of the product of the process. A valuable UN Secretariat Report, prepared in 1966, on the Progressive Development of the Law of International Trade, on the basis of existing international practice identified three possible methods:

1. normative regulations drawn up in the form of treaties accepted by states;

2. model laws to serve as guides for national adaptation and legislation and uniform laws to be incorporated by states into their legislation;

3. standard terms relating to commercial customs and practices adopted with an international body, notably the International Chamber of Commerce $(\text { ICC })^{33}$

Another, fourth method, illustrated by the activities of the Financial Action Task Force, has already been mentioned-the elaboration of supplementary processes, often on a recommendatory and voluntary basis. The first, second and fourth of those listed require state action. The third (considered further later) does not; it depends on the willingness of those entering into contracts to adopt the terms.

The work of UNCITRAL, over the past 40 years, set up by the General Assembly following that Secretariat Report, includes the three listed and indeed another category:

- 11 Conventions;

- 8 model laws and 8 model legislative guides;

- 12 Incoterms and similar texts endorsed by it, and 4 adopted by it.

The new category includes 11 recommendations and guides relating, for instance, to arbitration proceedings and cross-border insolvency cooperation.

I have already mentioned the principal example of my third group: the Incoterms and Uniform Customs and Practices prepared by the ICC. The ICC

Friendly Relations and Cooperation among States); GA Res 2205 (XXI) (17 December 1966) (establishing the UN Commission on International Trade Law).

${ }^{33}$ Progressive Development of the Law of International Trade: Report of the Secretary-General of the United Nations, UN Doc A/6396 (23 September 1966) paras 190-5, in UNCITRAL Ybk 1968-1970/I, 18. For an excellent discussion of the choice of method see R Cranston \& R Goode (eds), Commercial and Consumer Law: National and International Dimensions (1993) ch 1. 
first prepared Incoterms in 1936 for the purpose of facilitating global trade by providing trade terms that clearly defined the respective obligations of Parties and reduced the risk of legal complications. The latest version adopted in 2010, to quote UNCITRAL:

[O]ffered a simpler and clearer presentation of all the rules, taking into account of the continued spread of customs-free zones, the increased use of electronic communications in business transactions, heightened concerns about security in the movement of goods and changes in transport practices. $^{34}$

The ICC in fact asked UNCITRAL to endorse the revised text, which it did, congratulating the ICC for its further contribution to the facilitation of international trade by making Incoterms simpler and clearer, reflecting recent developments in international trade, and recommending the use of the terms, as appropriate, in international sales transactions. ${ }^{35}$ UNCITRAL had taken much the same action a few years earlier in respect of the 2007 revision of the Uniform Customs and Practice for Documentary Credits. ${ }^{36}$ The ICC, said UNCITRAL, in preparing the revision, had 'made a further contribution to the facilitation of international trade by bringing up to date its rules on documentary credit practice to allow for developments in the banking, transport and insurance industries and new technological applications. ${ }^{37}$

UNCITRAL has even taken similar action in respect of texts adopted by an intergovernmental body, UNIDROIT, but again in respect of a text the effectiveness of which essentially depends on the will of the parties to the contract, as it emphasised in the preamble to its decision. ${ }^{38}$

The final group under this heading is made up of the practices and standards of relevant occupational groups. Consider the broad terms to be found in certain maritime conventions. The Hague-Visby Rules for the Carriage of Goods by Sea, adopted in 1924, in Articles 3(1) and (2) require the carrier to:

(1) exercise due diligence to

(a) make the ship seaworthy;

\footnotetext{
${ }^{34}$ Work of the International Law Commission $\left(8^{\text {th }}\right.$ edn, 2012) para 143.

${ }^{35}$ Ibid, para 144.

${ }^{36} \mathrm{Ibid}$, paras $356-7$.

${ }^{37}$ Ibid, para 357.

${ }^{38}$ Ibid, para 140.
} 
(b) properly man, equip and supply the ship;

(c) make [...] all [...] parts in which goods are carried fit and safe for their reception, carriage and reservation;

(2) [...] properly and carefully load, handle, stow, carry, keep, care for, and discharge $[. .$.$] the goods. { }^{39}$

In the 90 years since that text was adopted shipping, including cargo handling, has changed in major ways. That is reflected in the resolution of the General Assembly adopting in 2008 the new United Nations Convention on Contracts for the International Carriage of Goods Wholly or Partly by Sea ${ }^{40}$ and in the preamble to the Convention itself. ${ }^{41}$ The General Assembly expressed its concern that:

[T] he current legal regime governing the international carriage of goods by sea lacks uniformity and fails to adequately take into account modern transport practices, including containerization, door-to-door transport contracts and the use of electronic transport documents. $^{42}$

The General Assembly expressed its conviction that:

[T] he adoption of uniform rules to modernize and harmonize the rules that govern the international carriage of goods involving a sea leg would enhance legal certainty, improve efficiency and commercial predictability in the international trade of goods and reduce legal obstacles to the flow of international trade among all States. $^{43}$

The preamble to the Convention recognises the significant contribution of the 1924 Convention and the related protocols and the 1978 Hamburg Convention

\footnotetext{
${ }^{39}$ Known formerly as the International Convention for the Unification of Certain Rules of Law relating to Bills of Lading, 25 August 1924, 120 LNTS 187, and adopting its present title with the passage of the Protocol to Amend the International Convention for the Unification of Certain Rules of Law relating to Bills of Lading, 23 February 1968, 1412 UNTS 127 (emphasis added).

${ }^{40} 11$ December 2008 (not yet in force).

${ }^{41}$ GA Res 63/122 (2 February 2009).

${ }_{42}^{4}$ Ibid, preamble, para 2.

${ }^{43}$ Ibid, preamble para 4.
} 
on the Carriage of Goods by Sea, ${ }^{44}$ but then mentions the later technological and commercial developments, and states the belief that:

[T] he adoption of uniform rules to govern international contracts of carriage wholly or partly by sea will promote legal certainty, improve the efficiency of international carriage of goods and facilitate new access opportunities for previously remote parties and markets, thus playing a fundamental role in promoting trade and economic development, both domestically and internationally.

The central obligation of 'due diligence' (now in Article 14) is stated in essentially the same terms as it was in 1924 in Article 3-the same adjectives and adverbs, with an addition in the paragraph equivalent to Article 3(2) to 'any containers supplied by the carrier'. The words are the same, the tests for liability also, but can that really be said of the content of the obligations 90 years after they were written when it comes to their being applied? Surely not.

The same question, no doubt, with the same answer, can be asked of the conventions for assistance and salvage at sea adopted since 1910. ${ }^{45}$ The 1910 and 1989 Conventions, and the related provisions contained in the 1958 Geneva Convention on the High Seas ${ }^{46}$ and 1982 UN Convention on the Law of the Sea, ${ }^{47}$ impose generally stated obligations on masters of ships, insofar as they can without serious danger to the ship, the crew or the passengers, to render assistance to any person found at sea in danger of being lost. After the development of long distance marine communications an obligation was imposed by the 1929 Convention on the Safety of Life at Sea ${ }^{48}$ to have that radiotelegraphic equipment on board. The Master on receiving a wireless distress signal was obliged to proceed with all speed to the assistance to the persons in distress unless he was unable or considered, in the special circumstances of the case, that it was unreasonable or unnecessary to do so. That obligation too was carried forward into the 1958,1982 and 1989 Conventions without any change in the general terms of the obligations. In the opinion of the ILC, ${ }^{49}$ the draft it proposed for the

\footnotetext{
4431 March 1978, 1695 UNTS 3.

${ }^{45}$ International Convention for the Unification of Certain Rules of Law relating to Assistance and Salvage at Sea and Protocol of Signature, 23 September 1910, Cd 6677; International Convention on Salvage, 28 April 1989, 1953 UNTS 165.

${ }^{46}$ Geneva Convention on the High Seas, 29 April 1958, 450 UNTS 82, Art 14

${ }^{47}$ UN Convention on the Law of the Sea, 10 December 1982, 1834 UNTS 397, Art 98.

${ }^{48}$ International Convention for the Safety of Life at Sea, 31 May 1929, 136 LNTS 81.

${ }^{49}$ ILC Articles concerning the Law of the Sea, ILC Ybk 1956/II, 265, commentary to Art 36.
} 
1958 text stated customary international law. To repeat the point, the practical content of those obligations has no doubt greatly changed since 1910 and 1929, given changes in technology and related maritime practices.

Such changes in application, even in the interpretation, of generally worded rules of law are not new. To anticipate M Portalis, one of Napoleon's code commissioners, quoted later, not everything can be written in precise terms. I give three instances:

1. how is the exception in the 1951 Refugee Convention ${ }^{50}$ of refugee status for a person who has been guilty of 'acts contrary to the purposes or principles of the United Nations' now to be applied to a major drug dealer;

2. how is tenancy protection legislation benefitting 'members of a family' or 'spouses' to be seen when social attitudes to non-married couples and gay couples have changed; or

3. does a power recognised in a treaty of 1854 to regulate the use of a border river on which the neighbouring state has freedom of navigation extend to regulation for the purposes of environmental protection? ${ }^{51}$

In such areas, and there are many more, developments beyond the law or certainly beyond the contemplation of those who wrote it may have a real impact on the current meaning and application of that law.

I earlier mentioned, instancing the work of the FATF, the 'other arrangements' which may, and frequently do, operate in support of binding international law. That Task Force is a means of facilitating and when appropriate regulating global transactions - the flow of people, goods, services including financingadditional to those listed earlier. I take a final example from APEC-the Asia Pacific Economic Cooperation, a most unusual entity, if it can even be called that. A former Australian Foreign Minister and Attorney-General, Gareth Evans QC, once referred to it as four adjectives in search of a noun or a verb. That is not quite right, given that the word 'Cooperation' does appear at the end of the list, but what does that word do? The entity, the process, brings together 21 economies from around the Pacific Rim, including Chinese Taipei and Hong Kong as well as mainland China. It is not a formal international organisation. It is not treaty

${ }^{50}$ Convention relating to the Status of Refugees, 28 July 1951, 189 UNTS 137.

${ }^{51}$ Pushpanathan v Canada [1998] 1 SCR 982; Dyson Holdings Ltd v Fox [1950] 2 KB 328; Fitzpatrick v Sterling Housing Association Ltd [2001] 1 AC 27; Dispute regarding Navigational and Related Rights (Costa Rica v Nicaragua), ICJ Reports 2009 p 213. 
based and, with one exception, it has not assisted in the preparation of binding texts. It operates on the basis of non-binding commitments which are undertaken on a voluntary basis. One major benefit of the process for members is the reduction in barriers to trade across borders. I give two examples from a wide range. In 2007 the APEC Single Window was established. ${ }^{52}$ It enables governments to process electronically information, documents and fees more quickly and accurately with the consequence that businesses and consumers benefit from faster clearance times, speeding up the supply chain. The goal is to establish that system for all member economies by 2020 . The second example concerns faster and more efficient travel for business people. That is facilitated by an APEC Business Travel Card. It allows:

business travelers pre-cleared, facilitated short-term entry to participating member economies. It removes the need to individually apply for visas or entry permits, saving valuable time, and allows multiple entries into participating economies during the three years the card is valid. Card holders also benefit from faster immigration processing on arrival via access to fast-track entry and exit through special APEC lanes at major airports in participating economies. ${ }^{53}$

Those and many other arrangements are developed through meetings of ministers, officials, experts and business people and others and much national deliberation and action. These are matters of practical cooperation where formal legal rules are not required; moreover, the preparation of such rules may cause difficulties both in terms of drafting and of national constitutional and legal processes.

\section{As a source of law for judges in hard cases}

In this part of the paper, I take two cases both with international elements, the first from the mid $18^{\text {th }}$ century, the second from the early $20^{\text {th }}$, but with a modern day complement. They both demonstrate, as I read them, the need for litigators

\footnotetext{
${ }^{52}$ APEC Sub-Committee on Customs Procedures, Single Window Strategic Plan (APEC, June 2007) <http://www.apec.org/About-Us/About-APEC// /media/Files/AboutUs/AchievementsBenefits/07_sccp2_013a.pdf> [accessed 7 November 2014].

${ }^{53} \mathrm{See} \quad<\mathrm{http}$ ///www.apec.org/About-Us/About-APEC/Business-Resources/APEC-BusinessTravel-Card.aspx> [accessed 7 November 2014].
} 
and judges to look broadly at possibly relevant material in arguing or deciding hard cases.

In 1759, Lord Mansfield was faced with a question about the freight to be paid by the owner of goods where the ship was taken by a French ship on the $17^{\text {th }}$ day of a 21 day voyage and was then retaken by an English privateer to which the owner of the freight, on the goods' return, paid half the value for salvage. Was the owner obliged to pay freight and if so at what rate? Yes, said Mansfield, and the rate was $1 / 2 \times 17 / 21$. How did he establish the rule of law 'certain and notorious' and fix that figure? Not by reference to any English statute or case (one decided in the House of Lords he said was also on point, the reasons in the judgment, for which he gave no reference, being given at length). Maritime law is not the law of a particular country but the general law of nations and he quoted Cicero: 'non erit alia lex Romae, alia Athenis; alia nunc, alia post hoc; sed et apud omnes gentes et omni tempore, una eadem que lex obtineit'. ${ }^{\text {' }}$

Accordingly, he began with the 'ancientist laws in the world (the Rhodian Laws) that the master shall have a rateable portion'. And Consolato del Mare, a Spanish book, agreed. Ever since The Laws of Oleron, a French book, he says, it has been settled thus. He refers to the Laws of Wisby and the Hansetown Laws and other sources which in turn cite extensive authorities with a final reference (before the House of Lords gets a mention) to an Ordinance of Louis XIV from $1681^{55}$

My second case is about piracy. Was actual robbery an essential element of piracy or did a frustrated attempt to rob also qualify? That question was put to the Privy Council in 1934 by a reference seeking its opinion. After three days of argument and only three weeks of deliberation Viscount Sankey, the Lord Chancellor, gave the report of their lordships that a frustrated attempt to commit a piratical robbery is equally piracy jure gentium. ${ }^{56}$ The opinion reviews 'opinions of jurisconsults ${ }^{57}$ and text book writers'-more than 20 of them-from Grotius to Kenny, from eight countries, several decisions, legislation, the Harvard Research $^{58}$ and the work of the League of Nations Codification Committee. The

\footnotetext{
${ }^{54}$ Cicero, De re publica (G W Featherstonhaugh ed, 1820) 3.33: 'not one law for Rome and another for Athens; nor one for now and another later; but one for all nations and for all time'.

${ }^{55}$ Luke v Lyde (1759) 97 ER 614.

${ }^{56}$ In Re Piracy Jure Gentium [1934] AC 586.

${ }^{57}$ In so far as I can determine this word is rarely used in writing in English, Article 2 of the Statute of the ICJ being one exception instance-but that was a direct copy from the French original in the Statute of the PCIJ. The Oxford English Dictionary gives no reference later than 1871.

${ }^{58}$ Harvard Research Draft Articles on Piracy (1932) 26 AJIL Spec Supp 739.
} 
Board makes several interesting points about:

1. the wider range of authority on which it may consult and act than that which it examines in determining municipal law;

2. the sources which include treaties, state papers, national legislation, national court decisions and last but not least opinions of jurisconsults;

3. the inductive process in which it was engaged;

4. the living and expanding character of international law which was not crystallised in the $17^{\text {th }}$ century; and

5. its refusal to hazard an overall definition of piracy. In support of that refusal, it recalled the words of Jean-Étienne-Marie Portalis, one of Napoleon's commissioners charged with preparing the Civil Code:

We have guarded against the dangerous ambition of wishing to regulate and foresee everything. A new question springs up. How then is it to be decided? To this question it is replied that the office of the law is to fix by enlarged rules the general maxims of right and wrong, to establish firm principles fruitful in consequences and not to descend to the detail of all questions which may arise upon each particular topic. ${ }^{59}$

The Board commented that a careful examination of the topic shows a gradual widening of the earlier definition of piracy to bring it from time to time more in consonance with situations either not thought of or not in existence when the jurisconsults were expressing their opinions. ${ }^{60}$

I now come forward a further 80 years to a decision of the Ninth Circuit of the US Court of Appeals in a case brought by the Japanese Institute of Cetacean Research against Sea Shepherd. The Court decided that Sea Shepherd was engaged in piracy in the Southern Ocean and issued appropriate injunctions. ${ }^{61}$ The Opinion, delivered by Chief Judge Kozinski, began with this striking paragraph:

59 [1934] AC 586, 600.

${ }^{60}$ Ibid.

${ }^{61}$ Institute of Cetacean Research, Kyodo Senpaku Kaisha Ltd, Tomiyugi Ogawa \& Toshiyuki Miura v Sea Shepherd Conservation Society \& Paul Watson, Court of Appeals, Ninth Circuit, No 12-35266, DC No. 2:11-cv-02043-RAJ, Order, 25 February 2013. 
You don't need a peg leg or an eye patch. When you ram ships; hurl glass containers of acid; drag metal-reinforced ropes in the water to damage propellers and rudders; launch smoke bombs and flares with hooks; and point high-powered lasers at other ships, you are, without a doubt, a pirate, no matter how high-minded you believe your purpose to be. ${ }^{62}$

In terms of the law, the Court relied primarily on the terms of the definition of piracy included in the 1958 and 1982 Conventions on the Law of the Sea. Those preparing that text, particularly the International Law Commission, in the 1950s were able to rely, as they willingly acknowledged, on the excellent Harvard Research of $1932,{ }^{63}$ which, in turn, was able to draw on at much more extensive body of material, with more time and wider participation than a Court process allowed. The ILC Members also had the advantage of the detailed comments of Governments on the draft proposals and the debates within the Commission itself. Those widely accepted codifications had further widened the scope of piracy from that found in 1934 and they also greatly facilitated the US Court's task. It no longer had to read across the material reviewed in 1934.

\section{Concluding thoughts}

I conclude with three reflections. The first is to be ready to challenge our comfortable ways of thinking. Leo Tolstoy ends War and Peace with a marvelous reflection on the Copernican Revolution. He drew a parallel between astronomy and history:

In the first case [that is of astronomy], we had to get away from a false sensation of immobility in space and accept movement that we

\footnotetext{
${ }^{62}$ Ibid, 2. Herman Melville should not be neglected. 'Whether owing to the almost omniscient look-outs at the mast-heads of the whaleships, now penetrating even through Behring's straits, and into the remotest secret drawers and lockers of the world; and the thousand harpoons and lances darted along all continental coasts; the moot point is, whether Leviathan can long endure so wide a chase, and so remorseless a havoc; whether he must not at last be exterminated from the waters, and the last whale, like the last man, smoke his last pipe, and then himself evaporate in the final puff': Moby Dick (1851) ch 105, quoted in part by Justice Marshall in Japan Whaling Association v American Cetacean Society, 478 US 221, 250 (1986). Neither Melville nor Kozinski were quoted in the recent whaling case in the ICJ: Whaling in the Antarctic (Australia v Japan; New Zealand intervening), ICJ, Judgment of 31 March 2014.

${ }^{63}$ Harvard Research, above n 58.
} 
could not feel. In the present case it is no less essential to get away from a false sensation of freedom and accept a dependence that we cannot feel. ${ }^{64}$

My second point is related. It is about cooperation, in Sennett's word, about being together, and about dialogue, talking together, rather than dialectic, which has a much more disputatious, argumentative sense. It is striking how much the law, reflecting a better side of life, emphasises cooperation.

Finally, to balance the emphasis in this paper on principle and on large ideas I recall the central role of facts. Many a beautiful hypothesis is destroyed by an ugly fact, declared T H Huxley ${ }^{65}$, a great Victorian scientist and Darwin supporter, or, to, relate the point to legal process, consider the marvelous cartoon by Leo Cullum in the New Yorker: a lawyer is earnestly asking the Judge, no doubt without success: 'Can we, just for a moment, Your Honor, ignore the facts?'66

\footnotetext{
${ }^{64}$ Leon Tolstoy, War and Peace: A Historical Novel (1869, tr 1886) 390-1.

${ }^{65}$ T H Huxley, 'Biogenesis and abiogenesis (1870)', in T H Huxley, Collected Essays, vol 8 (2011) 229.

${ }^{66}$ See <http://www.condenaststore.com/-sp/Can-we-just-for-a-moment-Your-Honor-ignorethe-facts-Cartoon-Prints_i8534482_.htm> [accessed 8 November 2014].
} 